\title{
SGK Prim Teşviklerinin SGK Denetmenlerinin Bakış Açıları ile Analizi ${ }^{1}$
}

\author{
Analysis of Social Security Institution Premium Incentives From The Perspectives of \\ Social Security Institution Inspector \\ Berna CIRITT BAYAR * \\ Idris VARICI **
}

\begin{abstract}
$\ddot{O} Z$
İşletmelerin üzerindeki en önemli yüklerden biri iş̧̧ilerin sigorta prim giderleridir. Araşttrmalar, primlerin yüksek olmasının işletmeleri kayıt dışı istihdama yönlendirdiğini ortaya koymaktadır. Bu nedenle ilgili maliyetin azaltılmasl, işgücü piyasasının düzenlenmesi, kayıtlı istihdamın özendirilmesi için işletmelere primlerle destekler sağlanmaktadır. Bu desteklerden biri de SGK (Sosyal Güvenlik Kurumu) primlerine yönelik teşviklerdir. SGK denetmenlerinin prim teşvik sisteminin uygulanmast ve denetlenmesi açısından büyük rol ve sorumlulukları bulunmaktadır. Bu anlamda SGK denetmenlerinin prim teşvik sisteminin işleyiş durumu, etkinliği ve verimliliği hususundaki beklentilerinin belirlenmesi bu çalışmanın amacıdır. Bu amaçla İstanbul ilinde görev yapan 110 SGK denetmeni ve denetmen yardımcısı bu çalışmanın örneklemini oluşturmuştur. Araştırma verilerinin elde edilmesinde anket yöntemi kullanılmıştır.
\end{abstract}

Araştırma sonuçlarına göre katıllmcıların beklentileri arasında "SGK prim teşviklerinin işletmelere mali destek sağlamasina yönelik beklentilerinin" en yüksek ve "SGK prim teşviklerinin denetimine yönelik beklentilerinin" ise en düşük ortalamaya sahip olduğu belirlenmişstir. Denetmenlerin büyük bir bölümü uygulanan teşviklerin daha küşük işletmeleri de kapsayacak biçimde genişletilmesi gerektiğini düşündükleri, teşviklerin haksız kazanç temin edilmesi gibi kötü niyetli ve usulsüz kullanımına dair yasal alt yapının tam olarak olușturulması konusunda tedirginlik hissettikleri tespit edilmiştir. Araştırmanın sonunda konu ile ilgilenen uzmanlara, denetmenlere, politika yapıclara ve akademisyenlere SGK teşviklerinin geliştirilmesine ve etkinliğinin artırlmasına yönelik önerilerde bulunulmuştur.

\author{
ANAHTAR KELIMELER \\ Sosyal Güvenlik Kurumu, Teşvik, Sosyal Güvenlik Kurumu Prim Teşviki
}

\begin{abstract}
One of the most important burdens on businesses is workers insurance premium expenses. Research reveals that high premiums lead businesses to shadow employment. Therefore, supports are provided to businesses for reduction of insurance cost, regulation of labor force market, supporting registered employment. One of these supports is Social Security Institution (SSI) Premium Incentive. SSI inspectors have important roles and responsibilities in terms of implementation and monitoring of the premium incentive system. In this sense, aim of this study is determining the expectations of SSI inspectors about operation, effectiveness, and efficiency of premium incentive system. For this purpose, the sample of this study is 110 SSI inspectors and inspector assistant working in Istanbul. Questionnaire was used to obtain research data.

As a result of this research "SSI premium incentives provide financial support to the businesses" had the highest average and "expectations regarding monitoring of SSI premium incentives" had the lowest average. Many inspectors think that premium incentives need to be expanded to smaller businesses. It has been determined that inspectors feel anxious about using incentives maliciously and illegal. Therefore, legal basis should be established. At the end of this study, some recommendations have been made to experts, inspectors, policymakers interested in about improving the SSI incentives and increasing their effectiveness.
\end{abstract}

KEYWORDS

Social Security Institution, Incentive, Social Security Institution Premium Incentive

\begin{tabular}{|c|l|c|}
\hline \multicolumn{2}{|c|}{ Makale Geliş Tarihi / Submission Date } & \multicolumn{1}{c|}{$\begin{array}{c}\text { Makale Kabul Tarihi / Date of Acceptance } \\
23.09 .2021\end{array}$} \\
\hline \multirow{3}{*}{ Atıf } & $\begin{array}{l}\text { Cirit Bayar, B. ve Varıcı, İ. (2021). SGK Prim Teşviklerinin SGK Denetmenlerinin Bakış Açıları ile Analizi. Selçuk } \\
\text { Üniversitesi Sosyal Bilimler Meslek Yüksekokulu Dergisi, 24 (2), 352-367. }\end{array}$ \\
\hline
\end{tabular}

\footnotetext{
${ }^{1}$ Bu makale 2020 yılında Ondokuz Mayıs Üniversitesi Lisansüstü Eğitim Enstitüsü İşletme Anabilim Dalı’nda, tamamlanan “Tarafları Bakımından SGK Prim Teşviklerinin Analizi: SGK Denetmenlerinin Bakış Açıları Üzerine Bir Araştırma” adlı yüksek lisans tezinden türetilmiştir.

* İstanbul Sosyal Güvenlik Kurumu Sosyal Güvenlik Denetmen Yardımcıs1, ciritberna@gmail.com, ORCID: 0000-0003-1917-0846.

** Doç. Dr. Ondokuz Mayıs Üniversitesi İ.İ.B.F. İşletme Bölümü Muhasebe-Finansman Anabilimdalı, idris.varici@omu.edu.tr, ORCID: 0000-00031825-0289.
} 


\section{GİRIŞ}

Çalışanlar, işletmede önemli bir role sahiptirler. Bu anlamda çalışanların en temel ihtiyaçlarını karşılaması için ekonomik birtakım desteklerin sağlanması gerekmektedir. Bu ihtiyacı karşılayan sistem sosyal güvenlik sistemi olarak hayat bulmaktadır. Sosyal güvenlik sisteminin etkin, adil, sürdürebilir ve çağdaş standartlara uygun yürütülmesinden sorumlu kurum ise sosyal güvenlik kurumudur.

Sosyal güvenlik kurumunun temel amaçlarından biri insanların yaşam kalitelerinin artırılması amacıyla sosyal ve ekonomik destek sağlanmasıdır. Bu desteklerin toplumun bütün kesimine sağlanması ve ulaştırılması temel hedef olarak yer almaktadır. Sosyal güvenliğin temel yapı taşı sosyal güvenlik kurumudur. Sosyal güvenlik kurumunun da kendi sürdürülebilirliğinin sağlanması gerekmektedir. Bu anlamda kurumun finansal desteğe ihtiyacı bulunmaktadır.

Sosyal güvenlik sisteminin etkili biçimde işletilebilmesi için sisteme finansal kaynak niteliğindeki en önemli aracın, bireylerin düzenli olarak ödemek zorunda oldukları primlerin olduğu değerlendirilmektedir. Ancak, içinde birçok unsuru barındıran prim sistemi, her ne kadar düzenli olarak ödenmesi gereken, cezai ve hukuki altyapısı bulunan bir husus olsa da sistemin iyi işletilebilmesi için etkili biçimde denetlenmesi gerekmektedir. $\mathrm{Bu}$ doğrultuda SGK denetmenlerinin sistemin işleyişine yönelik tecrübeleri önem arz etmektedir. Yapılan çalışma ile sosyal güvenlik sisteminin işletilmesinde en önemli araç olan prim sisteminin ve bu primlere yönelik uygulanan teşviklerin sistemin işletilmesi üzerindeki etkilerinin SGK denetmenleri gözünden değerlendirilmesi ve bu durum ile ilgili algılarının incelenmesi amaçlanmıştır.

Araştırmanın ilk kısmında SGK prim teşvikleri ile ilgili temel düzeyde teorik bilgiler verilmiştir. Bu bilgilerin temel düzeyde verilmesinin sebebi araştırmanın odak noktasının araştırma kısmı olması nedeniyle araştırmanın bütünlügünün bozulmamasının istenmesidir. İkinci bölümde araştırma soruları ayrıntılı olarak analiz edilmiştir. Son olarak araştırmanın sonuçları dikkate alınarak sonuç bölümü oluşturulmuş ve öneriler sunulmuştur.

\section{SOSYAL GÜVENLIKK KURUMU PRIMM TEŞVIKKLERİ}

SGK teşvikleri genelde çalışan açısından düzenlenmekte olup işletmelere bir anlamda maliyet avantajı sağlamaktadırlar. Çünkü çalışanların tamamı için her ay işletmelerin yatırdığı sigorta primlerinde teşviklerin olması işletmeler açısından personel maliyetlerini azaltıcı bir unsur olmaktadır. Bir anlamda destekle birlikte işletmelerin kayıt dışı istihdamın ve primlerin düşük maaşlardan yatırılmasının önüne geçilmeye çalışılmakta olup bütün çalışanlarının sigortalı hale getirilmesi birincil amaç haline gelmektedir.

Çünkü kayıt dışı istihdamın en önemli nedenlerinden biri olan ve işgücü maliyetlerini artıran sosyal güvenlik primleri gibi unsurlar başta üretim maliyetlerinin yüksekliğine, yüksek enflasyona, kar azalışına ve kurumsal yapının gelişmesine neden olabilmektedirler (Karaca ve Kaleli, 2019:773). Bu nedenle bir taraftan kurumun bir bütün olarak prim gelirlerinin azaltılmamas1, diğer taraftan işletmelerin prim ödeme alışkanlıklarının kazandırılması amacıyla kamu tarafından zamana ve şartlara bağlı olarak bir takım teşvikler sunulmaktadir.

Türkiye' de uygulanan teşvikler ve ilgili mevzuatları SGK ayrıntılı olarak belirtmekte olup, mevzuatlar da dikkate alınarak desteklerin araştırmanın yapıldığı andaki niceliksel durumu (www.sgk.gov.tr); 5510 sayılı Sosyal Sigortalar ve Genel Sağlık Sigortası Kanununda 7, 4447 sayılı İşsizlik Sigortası Kanununda 8, 4857 sayılı İş Kanununda 1, 5746 sayı1ı Araştırma, Geliştirme ve Tasarım Faaliyetlerinin Desteklenmesi Hakkındaki Kanunda 1, 5225 sayılı Kültür Yatırımları ve Girişimlerini Teşvik Kanununda 1, 2828 sayılı Sosyal Hizmetler Kanununda 1, 3294 sayılı Sosyal Yardımlaşma ve Dayanışmayı Teşvik Kanununda 1, 6331 sayılı İş Sağlığ1 ve Güvenliği Kanununda 1, olmak üzere toplamda 21 prim teşvik, destek ve indirim uygulamas1 bulunmaktadir.

Sosyal güvenlik sisteminin etkinliğinin artırılması, işgören ve işverenlerin primlerini düzenli ödemelerinin sağlanması gibi mikro ve istihdamın artırılması, toplumsal kültür ve dayanışmanın kuvvetlendirilmesi ve iş kazalarının önlenmesi gibi makro hedeflerle uygulamaya geçirilen SGK prim teşvikleri bu araştırmanın konusunu içermektedir. Bu kapsamda prim teşviklerinin, ekonomik istikrar, istihdam, iş güvenliği gibi farkl1 amaçlarla doğrudan ya da dolaylı olarak devlet katkısı şeklinde uygulandığı belirlenmiştir. SGK prim teşvikleri uygulamalarının hedeflenen sonuçlara ulaşması için ise iyi bir koordinasyona, takibe ve denetlemeye ihtiyaç duyulduğu değerlendirilmektedir. Bu doğrultuda birçok başlıkta uygulamaya koyulan SGK prim teşviklerinin etkinliğinin ve arzu edilen sonuçlara ulaşılıp ulaşılmadığının incelenmesi amacıyla çalışmanın uygulama bölümünde SGK denetmenlerinin bilgi birikimi ve tecrübelerinden faydalanılarak inceleme ve değerlendirmelerde bulunulmuştur. 
Teşviklerin her birinin mevzuatlarda ayrıntılı ve uzun bir şekilde ifade edildiği anlaşılmakta olup, bu makalede araştırma kısmının ön plana çıkarılması için teşviklerle ilgili kısa bilgilendirmeler yapılacaktır. Konu daha çok işveren açısından irdelenmiş olup zaman zaman işgören açısından da değerlendirmeler yapılmıştır.

\subsection{Sosyal Hizmetler Kapsamındakilerin İstihdamına Yönelik Teşvikler}

Bu teşvik kapsamı 2828 sayılı kanunla belirlenmiş olup, sigortalının işe başladığı tarihten itibaren 5 yıl süreyle bu destekten faydalanabildiği bilinmektedir. Bu teşvikten faydalanılması durumunda prime esas kazanç alt sınır üzerinden hesaplanan sigortalı ve işveren sigorta ve işsizlik sigortası primin tamamı devlet tarafindan karşılanacaktır.

İşyeri açısından teşvikten yararlanabilmenin koşulları, aylık prim ve hizmet belgesi kuruma yasal süresinde verilmiş olması, prim, idari para cezası ve bunlara ilişkin gecikme zammı ve cezası borcu bulunmaması, yapılandırılmış/taksitlendirilmiş borçların zamanında ve düzenli bir şekilde ödenmesine devam edilmesi ve sahte sigortalı bildiriminde bulunulmaması, kayıt dışı sigortalı çalıştırılmaması şeklindedir (www.sgk.gov.tr).

\subsection{Genç ve Kadın İstihdamı (18-29 Yaş Aralığında Olan Erkek ve 18 Yaşından Büyük Kadın) ile Mesleki Belgesi Olan Sigortalı İstihdamı İşveren Hissesi Sigorta Prim Teşviki}

4447 Sayı11 İşsizlik Sigortası Kanunun geçici onuncu maddesinde "31/12/2015 tarihine kadar işe alınan her bir sigortalı için geçerli olmak üzere, bu maddenin yürürlük tarihinden itibaren özel sektör işverenlerince işe alınan ve fiilen çalıştırılanların; işe alındıkları tarihten önceki altı aya ilişkin Sosyal Güvenlik Kurumuna verilen prim ve hizmet belgelerinde kayıtlı sigortalılar dışında olmaları, aynı döneme ilişkin işe alındıkları işyerinden bildirilen prim ve hizmet belgelerindeki sigortalı sayısının ortalamasına ilave olmaları ve bu maddede belirtilen diğer koşulları da sağlamak kaydıyla, 5510 sayılı Kanunun 81 inci maddesinde sayılan ve 82 nci maddesi uyarınca belirlenen prime esas kazançları üzerinden hesaplanan sigorta primlerinin işveren hisselerine ait tutarı, işe alındıkları tarihten itibaren İşsizlik Sigortası Fonundan karşılanır" hükmü yer almaktadır (www.mevzuat.gov.tr).

Özel sektör işletmeleri, Aralık 2020 yılına kadar işe başlattıkları her bir sigortalı için prime esas olan maaşları üstünden hesaplanan sigorta primi işletme hissesi miktarında teşvikten faydalanabilmekteydi. $\mathrm{Bu}$ teşvikten yararlanabilmek için sigortalı çalışanının, ortalama sigortalı sayısına ek olarak bulundurulması, işletmeye dair prim, idari para cezası ve bunlara dair gecikme zammı ve cezası borcunun olmaması/ borçlarının bazı yasalar ile yapılandırılmış ya da taksitlendirilmiş olması ve bu yapılandırmanın sürüyor olması, aylık prim ve hizmet belgesinin kanuni zamanı içerisinde SGK'ya verilmesi ve primlerin kanuni süresi içinde verilmesi gerekmektedir (www.sgk.gov.tr).

\subsection{Malullük, Yaşılık ve Ölüm Sigortaları Prim Oranının İșveren Hissesinden Beş Puan İndirimi}

Malul kalma, yaşl1lık, ölüm sigortaları primi işletme hissesinden beş puanlık bölümünün, 5510 sayılı Kanun'unun 81. maddesine, 2008 y1lı ve 5763 sayılı İş Kanunu 24. maddesi ile ilave edilen (1) bendi yasal dayanağına göre Hazine tarafından karşılanması prim indirim teşviki olarak hüküm altına alınmıştır. Hazinenin işletmelere sağladığı bu destek 2016'da yayımlanan 6745 sayılı Yasa ile prim borcu bulunmayan ve süresinde ödeyen 4/1-b kapsamı içindeki köy ve mahalle muhtarları ile hizmet akdi güdülmeksizin kendi namına ve hesabına bağımsız çalışanlar için de kullanılmaktadır (İzmirlioğlu, 2019: 26). Sözü edilen kanunlara göre özetlenecek olunursa; özel sektör işletmeleri, iş gördürdükleri sigortalılara dair malul kalma, yaşl1lık ve vefat sigortaları primlerinin işletme hissesinin $(\% 11)$ beş puanlık bölümüne isabet eden miktar kadar indirimden faydalanabilmektedir.

$\mathrm{Bu}$ beş puanlık prim teşvikinin amacı işletmelere ekonomik destek sağlamaktan ziyade prim borçlarını vadesinde ödeyen işletmeleri ödüllendirerek prim borçlarının vadesinde ödenmesini teşvik etmek şeklinde algılanabilir. Sosyal devlet anlayışı ile hareket eden kamu bir taraftan düzenlediği teşvik uygulamaları ile vadesinde borçlarını ödeyenleri özendirerek yüksek olan sigorta prim oranlarının düşürülmesini sağlamak isterken, diğer taraftan kendi bütçesini oluşturmak adına prim alacaklarını vadesinde tahsil etmek şeklinde bir politika izlemektedir (Şeker ve Özdemir, 2010:2-3).

Primden faydalanabilmesi için aylık prim ve hizmet belgesinin/muhtasar ve prim hizmet beyannamesinin kuruma yasal süresinde verilmiş olması, primlerin yasal süresi içinde ödenmesi, prim, idari para cezası ve bunlara ilişkin gecikme zammı ve cezası borcu bulunmaması, varsa bu borçlar yapılandırılmış, taksitlendirilmiş ve düzenli ödeniyor olması, kayıt dışı sigortalı çalıştırılmaması/sahte sigortalı bildiriminde bulunulmaması, işverenin 5335 sayılı Kanunun 30 uncu maddesinin ikinci fikrası kapsamına giren kurum ve kuruluşlardan olmaması, yapılan işin 2886, 4734 sayılı Kanunlar ve 4734 sayılı Kanunun 3. maddesi 
kapsamında veya uluslararası anlaşmalara istinaden alım ve yapım işlerinden olmaması gerekmektedir (www.sgk.gov.tr).

\subsection{Uzun Vadeli Sigorta Kolları Primi İşveren Hissesinin Beş Puanının Devlet Tarafindan Karşılanması}

İşverenlerin sigorta sistemi ile ilgili sürekli ifade ettiği en ciddi eleştirilerin belki de en önemlisi prim oranlarının fazlalığıdır. 5510 sayılı Yasa ile gerçekleştirilen en beğenilen düzenlemelerden bir tanesi de primlerin azaltılmasına dair olarak geliştirilen 5 puanlık işletme prim hissesinin hazine tarafından veriliyor olmasıdır. Ödenmesi mecburiyeti olan primlerin 5 puanlık işletme hissesi bölümünün hazine aracılığ karşılanması işletmenin prim maliyetinin \%15 değerinde düşürülmesi anlamını taşımaktadır. 5 Puanlık prim desteği esas şekliyle işçilik maliyetinin $\% 5$ ve prim maliyetinin $\% 15$ daha aşağı düşürülmesi anlamını taşımaktadır (Özdamar, http://archive.ismmmo.org.tr). Teşvikten yararlanma koşulları diğerlerine benzerdir. Prim borcu olan, kayıt dışı çalışan bulunduran ve prim borçlarını düzenli ödeyenlerin yararlanabildiği bir teşvik olarak bilinmektedir.

İşletmenin iş gördürdükleri sigortalıların prim tutarını noksan hesaplaması ve bu olayın daha sonra belirlenmesi 5 puanlık prim teşvikinden faydalanmaya engel olmamaktadır. İşletmenin daha sonra geriye dönük prim belgesi hazırlayıp sunması daha önce alınmış olunan 5 puanlık prim desteklerini geçersiz saymaz. Yalnızca sonradan verilen tahakkuk için 5 puanlık indirim verilmez.

\subsection{Gelişmekte Olan Bölgelerdeki İşverenlerin Çalıștırdıkları Sigortalılar Adına Ödeyeceği Uzun Vadeli Sigorta Kolları Primi İşveren Hissesi Teşvikine İlaveten Uygulanan Prim Teşviki}

Ekonomik gelişmişlik düzeyi düşük olan illerin kalkınmasına faydası olacağı düşünülen teşvik kapsamında bazı il ve ilçelerde uygulanmış olan bir teşvik türüdür. Buna göre Ocak 2013 tarihinden geçerli olmak üzere uygulanan teşvik 51 il 2 ilçe için geçerli olmuş bir teşvik türü idi. Sayılan bu yerlerdeki özel sektöre ait işyerleri 2013-2020 yılları arasında 5 puanlık prim indirimine ilave olarak 6 puanlık sigorta primi teşvikinden yararlanmışlardır. Teşvikten öncelikle prime esas kazanç üst sınırına kadar olan kazançlar üzerinden 5 puanlık indirim ve sonrasında prime esas kazanç alt sınırına kadar kazançlar üzerinden ilave 6 puan indirim olarak yararlanılmıştır (Özcan, 2021). İlgili teşvik birkaç defa uzatılmış nihayetinde bitiş tarihi olarak 31.12.2021 tarihi olarak belirlenmiştir (www.verginet.net).

\section{6. İşbaşı Eğitim Programlarını Tamamlayanların İstihdamına Yönelik Teşvikler}

İş başı eğitim İŞKUR tarafindan hem teorik hem de mesleki deneyim kazanılması yönünden düzenlenen bir eğitimdir. $\mathrm{Bu}$ eğitimde hem mesleki tecrübe elde edilirken hem de belli bir ücret elde edilmektedir. $\mathrm{Bu}$ anlamda istihdam edilebilirlik konusunda katılımcılara faydası olan bir eğitim türüdür. Farklı sektörlere göre farklı eğitim süreleri bulunmaktadır. İş başı eğitimi tamamlayanların istihdamı şartıyla farklı sektörlerde farklı yaş gruplarına farklı sürelerle destek sağlanmaktadır. Bu destekler arasında prim teşvikine yönelik destekler de bulunmaktadir.

\section{7. İşsizlik Ödeneği Alanları İşe Alan İşverenlere Yönelik Teşvikler}

Son 6 ay içinde sigortalı sayısına ilave olarak işsizlik ödeneği alan bir kişinin istihdamı halinde kısa vadeli sigorta priminin \%1'i olmak üzere işçi ve işveren payı sigorta primleri ile genel sağlık sigortası primi kalan süre boyunca fondan karşılanmaktadır (Nurdoğan, 2019:96). Kalan sürenin hesaplanmasında örneğin işsizlik ödeneği alma hakk1 6 ay kalan bir işçi için 6 aylık bir teşvik süresi geçerli olacaktır.

\section{8. İŞKUR’a Kayıtlı İşsizlerin İşe Alınmasına Yönelik Teşvikler}

4447 sayılı İşsizlik Sigortası Kanununa eklenen geçici 19'uncu madde ile kadın, engelli ve gençler için ilave istihdam sağlayan özel sektör işverenlerine yönelik prim desteği sağlanarak kayıtlı istihdamın artırılması amaçlanmıştır. IŞKKUR'a kayıtlı ve işe alındıkları aydan önceki üç ayda on günden fazla 5510/4-a,b,c kapsamında sigortalılıkları bulunmayan işsizlerden 1.1.2018- 31.12.2020 tarihleri arasında işçi istihdam eden özel sektör işverenlerine on iki ay süre ile prim desteği tutarı fondan karşılanmaktadır. Prim desteği miktarı, sektörden sektöre değişmektedir. İmalat ve biliş̧im sektörlerindeki işyerleri için sigortalının Prime Esas Kazancı üzerinden, diğer sektörlerde faaliyet gösteren işyerleri için prim desteği ise prime esas kazancı alt sınırı üzerinden hesaplanacak sigortalı ve işveren hissesi primlerinin tamamı olarak uygulanmaktadır (www.mevzuat.gov.tr, Nurdoğan, 2019:93-94). 


\subsection{AR-GE Faaliyetlerinin Desteklenmesine Yönelik Teşvikler}

İşletmelerin Araştırma Geliştirme faaliyetlerine yönelik çeşitli kurumların farklı teşvikleri ve destekleri bulunmaktadır. Bu desteklerin her biri farklı mevzuatlarla yasallaşmıştır. Bu kapsamda sosyal güvenlik primleri ile ilgili teşvik kısmı iki ayrı mevzuatta yerini almıştır. Ücreti gelir vergisinden muaf personel ile ARGE tasarım ve destek personeli için hesaplanan sigorta primi işveren hissesinin yarısı devlet tarafından karşılanmaktadır (Bozdemir, 2018:17). Öte yandan malullük, yaşlılık ve ölüm sigortası primlerinin işveren hissesinden uygulanacak 5 puanlık indirimle birlikte uygulanması durumunda önce 5 puanlık indirim ardından kalan üzerinden işveren hissesinin yarısı olarak AR-GE teşviki uygulanacaktır. Bu teşvik 2008 yılında başlayıp 2023 yılının sonuna kadar devam edecektir (Oral, 2019:236, www.sgk.gov.tr).

\subsection{Yatırımlara Devlet Yardımları Hakkında Kararlar Gereği Uygulanan Teşvikler}

İlgili teşvik yatırım bölgeleri ve yatırımın büyüklüğüne göre değişmektedir. 2009 yılında başlayan teşvik halen devam etmektedir. Özellikle büyük ölçekli yatırımlar, stratejik yatırımlar ve bölgesel teşvik uygulamaları kapsamında yararlanılabilmektedir. Bunun için sigorta primi işveren hissesi desteği içeren teşvik belgesinin alınmas1 gerekmektedir (www.istihdamatesvik.com).

\subsection{Yurt Dışına Götürülen/Gönderilen Sigortalılara Beş Puanlık İndirim Teşviki}

$\mathrm{Bu}$ teşvikte işletmenin yurtdışında çalıştırdığı çalışanına ait bir indirim söz konusudur. Buna göre işverenlerin yurt dışındaki işyerlerinde çalıştırılmak üzere yurt içinden götürülen/gönderilen sigortalıların olması durumunda sigortalıların prime esas kazançları üzerinden hesaplanan genel sağlık sigortası primlerinin işveren hissesinin 5 puanlık kısmı devlet tarafından karşılanmaktadır (www.sgk.gov.tr). Bu teşvikten yararlanılabilmesi diğer teşviklerin çoğunda olduğu gibi geçmiş sigorta borcu ve para cezası ile bunlara ilişkin gecikme borçları bulunmamalıdır. Bunun yanında kayıtışı çalışanı bulunmaması gerekmektedir.

\subsection{Kültür Yatırımları ve Girişimlerine Yönelik Teşvikler}

Sürekli bir teşvik olarak kültür yatırım belgesi almış olan işyerlerinde çalışanların sigorta primi işveren hissesinin 3 yıl boyunca \%50'si, kültür girişim belgesi almış işyerlerinde çalışanların ise prime esas kazançları üzerinden hesaplanan sigorta primi işveren hissesinin 7 yıl boyunca $\% 25$ 'i, Kültür ve Turizm Bakanlığ bütçesine konulan ödenekten karşılanacaktır. Bunun için işveren tarafın kurumlar vergisi mükellefi olması, aylık prim ve hizmet belgesinin yasal sürede verilmiş olması, prim, idari para cezası ve bunlara ilişkin gecikme zammı ve borcunun olmaması, bu şekilde borçlar varsa bile yapılandırılmış, taksitlendirilmiş ve düzenli olarak ödeniyor olması gerekmektedir (Oral,2019:236). Bu teşvikten yararlanmak için aynı anda başka teşvikten yararlanmanın mümkün olmadığı biliniyordu. Fakat daha sonra yapılan düzenlemelerle işverenin aynı dönemde 5510 sayılı Kanuna göre belirlenen 5 puanlık prim indiriminden de yararlanılabilir hale getirilmiştir. Buna göre önce 5 puanlı prim indirimi sonra kültür yatırımları ile ilgili yukarıda ifade edilen teşvik kullanılabilecektir (İzmirlioğlu,2019:75).

\subsection{Asgari Ücret Desteği}

Son yıllarda asgari ücrete gelen artışlarla birlikte işverenlerin işçilik maliyetlerini bir nebze olsun azaltmak adına uygulanan bir teşvik türüdür. İlk olarak 2016 yılında başlayan teşvik uygulaması 2017,2018 yılları için de geçerli iken, 2019 yılında yeniden uzatılmıştır (Koç,2019:110). 2019 yılında 500 ve üzerinde uzun vadeli sigortalı çalıştıranlar aylık 100,80,-TL, 500 kişinin altında sigortalı çalıştıranlar 150 TL asgari ücret desteği sağlanmaktadır (Nurdoğan, 2019:96). 5510 sayılı Kanunun geçici 80. Maddesinin dayandığı hükümlere göre; 2020 yılı Ocak ila Aralık ayları/dönemi için günlük 2,50 Türk Lirası, bu işverenlerin Kuruma ödeyecekleri sigorta primlerinden mahsup edilip ve bu tutar İşsizlik Sigortası Fonundan karşılanmaktadır (www.sgk.gov.tr).

\subsection{Sosyal Yardım Alanların İstihdamına Yönelik Teşvikler}

2016 tarihinden itibaren başlamak üzere, işe giriş tarihinden önceki son bir yıl içerisinde sosyal yardımlardan nakdi olarak en az bir defa yararlanmış olanların ikamet ettiği hanede bulunanların istihdamı halinde prime esas kazanç alt sınır faktöründen hesaplama yapılarak sigorta primi işveren teşviki oranının tamamı Aile, Çalışma ve Sosyal Hizmetler Bakanlığı tarafından karşılanmaktadır. Destekten yararlanma süresi sigortalının işe başladığı tarihten itibaren bir yıldır (www.sgk.gov.tr). Bu teşvikle özellikle kırsal bölgelerde yaşayan ve sosyal destekten yararlananların istihdamını teşvik etmek üzere tasarlanmıştır (Kurt,2017). 


\subsection{5. İş Kazalarının Önlenmesine Yönelik Teşvikler}

İş kazalarının işyerine ve ülke ekonomisine maliyeti oldukça yüksektir. Bu nedenle çok tehlikeli sınıfta yer alıp ondan fazla çalışanı bulunan ve üç yıl içinde ölümlü veya sürekli iş göremezlikle sonuçlanan iş kazası meydana gelmeyen işyerlerinde çalışanların işsizlik sigortası işveren hissesi teşviki olarak bir sonraki takvim yılından geçerli olmak üzere ve üç yıl süreyle \%2 yerine \%1 olarak alınacaktır (Esen,2018:66, www.sgk.gov.tr). Bu teşvik 2019 yılından itibaren başlamış olup, teşvikten yararlanmaya başladıktan sonra ölümlü veya sürekli iş göremezlikle sonuçlanan iş kazası meydana gelmesi hâlinde takip eden aydan itibaren bu teşvikten yararlanamaz. Ancak daha sonra şartların yeniden sağlanması durumunda yeniden yararlanmaya başlayabilir (Işıkl1, 2018). Bu şekilde iş kazalarını önleyici bir teşvik söz konusudur. Bu uygulama ile aslında işveren ve ekonomi açısından maddi ve manevi maliyetlerin önüne geçilmek istenmektedir.

\subsection{Sosyal Hizmetler Kapsamındakilerin İstihdamına Yönelik Teşvikler}

2828 say1lı Kanunun ek 1 inci maddesi kapsamına giren kişilerin istihdamı halinde prime esas kazanç alt sınır üzerinden hesaplanan sigorta primi ve işsizlik sigortası priminin sigortalı ve işveren hissesinin tamamı sigortalının işe başladığı tarihten itibaren 5 yıl süreyle Hazine ve Maliye Bakanlığı tarafından karşılanmaktadır (www.sgk.gov.tr).

\subsection{Bağımsız Çalışan Sigortalıların Uzun Vadeli Sigorta Kolları Primlerinin Beş Puanının Devlet Tarafindan Karşılanması}

Sigorta prim teşvikleri daha çok, işletmelere, çalıştırdıkları işçiler için ödenmekle birlikte ilk defa bu uygulama ile bağımsız çalışanlar da teşvik kapsamına dahil edilmiştir. Anılan teşvikle amaçlanan kendi adına çalışanların sigorta primlerinin zamanında düzenli bir şekilde ödenmesini sağlamaktır. Bu teşvike dâhil olanların sigorta primlerinin tamamı kendileri tarafından ödenmektedir. Buna bağlı olarak 4/b kapsamındaki kişiler için \%20 olan malullük, yaşlılık, ölüm sigortası miktarından \%5 indirim yapılarak, ödenmesi gereken bu oran \%15 olarak belirlenmiştir (İzmirlioğlu, 2019:30).

\section{ARAŞTIRMA}

\subsection{Araştırmanın Amacı ve Önemi}

Ülkemizde 2008 yılından itibaren uygulamaya konulan SGK Teşvik Sistemi'nin ekonomik, sosyal ve toplumsal açıdan oldukça önemli sonuçları olduğu değerlendirilmektedir. Sistemin uygulaması hedeflenen yükssek istihdam oranlarına ve üretim kapasitesine ulaşılması, kayıp ve kaçağın önlenmesi gibi bazı temel şartların yerine getirilmesi ile sağlanabilmektedir. Bu bağlamda her alanda faaliyet gösteren işletmeler, gereken koşulları sağlamak şartıyla birçok teşvikten faydalanabilmektedir. Bu sayede işletmeler, işçilik maliyetlerini azaltabilmekte, vergi avantajları sağlayabilmekte ve AR-GE gibi alanlarda doğrudan yatırım desteği alabilmektedirler.

Ancak, sistemin etkin ve verimli olarak çalışabilmesi için, iyi bir denetim mekanizmasının kurulması gerekmektedir. Özellikle SGK denetim uzmanlarına bu noktada büyük sorumluluklar düşmektedir. Gerek bilinçsiz gerekse kasten yapılabilecek hataların önlenmesi kaynakların doğru biçimde kullanılmasını sağlamaktadır. Dolayısıyla, ülkemizde uygulanan teşvik sisteminin tüm detayları ile ortaya konulması, ayrıca, başarıyla uygulanan ya da geliştirilmesine ihtiyaç duyulan unsurlarının incelenmesi önem taşımaktadır.

Yapılan çalışmada, Türkiye'de, istihdam yaratma, kayıt dışılığı azaltma, üretimi ve verimliliği artırma gibi bazı ekonomik hedeflerle sosyal güvenlik sisteminin daha etkili ve verimli işletilebilmesi adına uygulanan "teşvik" sisteminin incelenmesi amaçlanmıştır. Bu doğrultuda, sistemi en iyi tanıdığı düşünülen SGK denetmenlerinin görüşleri alınarak, sistemde öne çıkan olumlu ve olumsuz hususlar tüm yönleriyle değerlendirilmiştir. Çalışmanın ortaya koyduğu sonuçları itibariyle hem literatüre katkı sağlayacağı hem de konuyla ilgilenen girişimcilere ve uzmanlara önemli öneriler sunacağı değerlendirilmektedir.

\subsection{Araştırmada Veri Toplama Yöntemi}

Çalışmada, konuya ilişkin uygulamaların mevcut durumları betimlenmeye çalışıldığı için "tarama modeli’nden de faydalanılmıştır. Bahse konu teknikler ışı̆̆ında araştırmanın ana problemini oluşturan, SGK denetmenlerinin prim teşvikleri konusundaki bakış açılarının nasıl olduğu hususu tarama modeli ile ortaya konulmaya çalışılmıştır. Araştırma kapsamında ayrıca, uzman görüşlerinin belirlenmesi ve araştırma kapsamındaki verilerin elde edilmesi için SGK denetmenlerinden oluşan bir çalışma grubuna araştırmacılar tarafından geliştirilen bir "anket" uygulanmış ve anketten elde edilen veriler doğrultusunda ulaşılan bulgular yorumlanmıştır. 
Anket, katılımcılara yüz yüze uygulanmış ve anket formunun yazılı olarak doldurulması sağlanmıştır. Veri toplama aracı olarak kullanılan anket formu iki bölümden oluşmaktadır.

Anketin güvenirlik değerini gösteren Cronbach Alfa $(\alpha) 0.755$ olarak bulunmuştur. Bulunan bu değer araştırmada kullanılan anketin güvenilir $(\% 75,5)$ olduğunu ortaya koymaktadır. Ayrıca, KMO and Bartlett's Test of Sphericity Analizi anketin geçerliliğinin belirlenmesinde kullanılan bir testtir. Bu kapsamda, araştırmada kullanılan anketin KMO değeri=0.617 bulunmuştur. Buna göre anketteki alt faktörlerin araştırmanın problem ve alt problemlerinin analizi için yeterli seviyede ve geçerli olduğu değerlendirilmektedir.

\subsection{Araştırmanın Örneklemi ve Kapsamı}

Araştırmaya ait evren; İstanbul'daki SGK denetmen ve denetmen yardımcılarıdır. Araştırmanın örneklemi ise; ekonomik ve zamansal faktörler göz önünde tutularak İstanbul ilinde görev yapan ve araştırmaya katılmay1 gönüllü olarak kabul eden 110 SGK denetmeni ve denetmen yardımcısı olarak belirlenmiştir. İstanbul'da faaliyet gösteren işletmelerin daha büyük ölçekli olması ve daha geniş iş alanlarını kapsaması nedeniyle araştırma örnekleminin İstanbul ilinde görev yapan SGK denetmen ve denetmen yardımcıları arasından seçilmesine karar verilmiştir. Ayrıca, çalışmanın yapıldığı tarihte Covid-19 küresel bulaşıcı hastalığın ülkemizde de yaygın olması nedeniyle örneklem sayısı artırılamamıştır.

Araştırma İstanbul ili ile sınırlı tutulmuştur. Araştırma sorularını içeren anket araştırmacılar tarafından yüz yüze görüşme yapılarak gerçekleştirildiğinden ulaşılabilirlik ve zaman kısıtı nedeniyle sayı sınırlı tutulmuştur. Ayrıca SGK prim teşvikleri sürekli değişkenlik gösterdiğinden araştırmanın yapıldığı zaman dilimine kadar uygulanan teşviklerle ilgili sorular anket formunda yer almıştır. Yeni çalışmalarda prim teşvikleri ile ilgili değişkenlik gösteren soruların anket formuna dahil edilmesi olağandır. Yine de araştırmanın temel amacı genel olarak SGK prim teşvikleri ile ilgili denetçi ve yardımcılarının bakış açılarını analiz etmek olduğundan araştırma sonuçları yeni gelen veya gelebilecek prim teşviklerine de rehberlik edebilecek niteliktedir.

\subsection{Verilerin Analizi}

Araştırmada kullanılan ölçekler aracılığıyla ulaşılan veriler, SPSS (Statistical Package for Social Sciences) Version 25.0 paket programı ile ön ve ileri analiz işlemlerine tabi tutulmuştur. Verilerden yola çıkarak ön analiz kapsamında yüzde (\%) ve aritmetik ortalama $(\overline{\mathrm{x}})$ gibi tanımlayıcı istatistiksel sonuçlar belirlenmiş ve grafiklerle gösterilmiştir.

SGK denetçileri mesleğinin ilerleyen yıllarında daha fazla tecrübeye sahip olduğundan teşvikler konusundaki denetim faaliyetlerinde daha bilgili oldukları, mesleğe yeni başlayan denetmen yardımcılarında ise bu hususta beklentinin biraz daha zayıf olduğu düşünülmektedir. Bu bağlamda araştırma verileri arasında anlamlı farklılıkların ortaya çıkması öngörülmektedir. Dolayısıyla çalışmada değişkenler arasında istatistiksel farklılıkların olup olmadığının belirlenmesi için Bağımsız Örneklem t Testi (Independent Samples t Test) ve Tek Yönlü Varyans (One Way ANOVA) Analizi testi kullanılmıştır. Anlamlı farklı1ığın olduğu sonuçlarda, bu farkın hangi grup lehine oluştuğunun anlaşılması için çoklu karşılaştırma testlerinde post-hoc (BSD) test kullanılmış ve görselliğin artırılması amacıyla da çapraz tablolardan yararlanılmıştır.

\subsection{Araştırmanın Bulguları}

\subsubsection{Tanımlayıcı İstatistikler}

Katılımcılar denetmen ve denetmen yardımcıları olup ilgili meslekleri icra edenlerin demografik özellikleri aşağıdaki gibidir.

Tablo 1: Demografik Özellikler

\begin{tabular}{|l|c|c|c|c|c|}
\hline \multicolumn{1}{|c|}{ Cinsiyet } & Sayı (\%) & Yaş & Sayı (\%) & Mesleki Deneyim Durumu & Sayı (\%) \\
\hline Kadın & $39(35,5)$ & $18-24$ & $1(0,9)$ & 1 yıldan az & $11(10,0)$ \\
\hline Erkek & $71(64,5)$ & $25-34$ & $76(69,1)$ & $1-5$ yıl & $57(51,8)$ \\
\hline & & $35-44$ & $22(20,0)$ & $6-10$ yıl & $25(22,7)$ \\
\hline & & $45-54$ & $11(10,0)$ & $11-15$ yıl & $17(15,5)$ \\
\hline Ĕ̈itim Durumu & Sayı (\%) & Kurumdaki Unvan & Sayı (\%) & & \\
\hline Lisans & $84(76,4)$ & SGK Denetmeni & $55(50,0)$ & & \\
\hline Yüksek Lisans & $24(21,8)$ & SGK Denetmen Yrd. & $55(50,0)$ & & \\
\hline Doktora & $2(1,8)$ & & & & \\
\hline
\end{tabular}


Tablo 1'e göre araştırmaya katılan erkek denetçi sayısının kadın denetçi sayısından daha fazla olduğu, 2534 yaş aralığında bulunan denetçilerin yaş grupları içinde en büyük orana sahip oldukları, lisans mezunu olan denetçilerin yüksek lisans ve doktora mezunu olan denetçilere göre oldukça fazla sayıda olduğu tespit edilmiştir. Sosyal Güvenlik Kurumu toplumun tamamına hizmet veren, sürekli değişen bir mevzuata sahip bir kurumdur. SGK denetmenleri de toplum ile kurum arasında köprü görevi görmekte olan bir meslek olduğundan; meslek mensuplarının eğitim seviyesinin lisansüstü seviyesinde olması toplumun bilinçlendirilmesi açısından büyük önem taşımaktadır. SGK denetmenleri her yıl bazı dönemlerde rehberlik faaliyeti göstermektedir ve bunun için Sosyal Güvenlik Kurumunda çeşitli eğitimler verilmektedir. Araştırmaya katılan SGK denetmenlerinin vermiş olduğu cevaplar göz önünde bulundurulduğunda; lisansüstü eğitim seviyesine sahip denetmenlerin, işveren ve işçilerin işlemleri hakkında daha kapsamlı bilgi paylaşımında bulundukları düşünülmektedir.

SGK denetmen yardımcıları göreve başlamalarının üzerinden 3 yıl geçtikten sonra yeterlilik sınavına girmektedirler. Yeterlilik sınavından başarılı olan denetmen yardımcıları, denetmen unvanı ile mesleklerine devam etmektedirler. Bu nedenle kurum içerisinde denetmen ve denetmen yardımcılarının sayısı her yıl yapılan yeterlilik sınav sonucuna göre değişiklik göstermekte olup, araştırmaya katılan denetmen ve denetmen yardımcısı sayısının birbirine eşit olduğu belirlenmiştir.

Öte yandan mesleki deneyimi 1-5 y1l arasında bulunan grubun tüm gruplar içerinde en büyük frekansa sahip olduğu gözlenmiştir. Sosyal Güvenlik Kurumunda 2008 y1lında Sosyal Güvenlik Kontrolör Memurluğu kadrosu bulunmakta idi. 2011 yılında ise Kurum içinde açılan SGK denetmenliği kadrosu sınavı ile Sosyal Güvenlik Kontrolör Memurluğu kadrosundan SGK denetmeni unvanı ile görevine devam eden personel sayısının, daha sonraki yıllarda kayıt dışı istihdamla mücadele kapsamında arttırılması katılımcıların mesleki deneyimleri arasındaki farkın sebebi olarak değerlendirilmektedir.

\subsubsection{Frekans Analizi Sonuçları}

Araştırmada kullanılan anket formuna katılımcıların verdikleri cevapların ortalama puanları Tablo 2'de yer almaktadır. Tanımlayıcı istatistiklerin dışında kalan anket soruları araştırmacılar tarafından 9 ana başlıkta gruplandırılmıştır. Bu gruplama dikkate alınarak sorulara verilen cevapların ortalamaları aşağıdaki tablolarda yer almaktadir.

\section{Tablo 2. Araştırmaya Katılan SGK Denetmenlerinin SGK Prim Teşviklerinin Genel Özelliklerine Yönelik Beklenti Ortalamaları}

\begin{tabular}{|c|c|}
\hline SGK Prim Teşviklerinin Genel Özelliklerine Yönelik Beklentiler & Ortalama Puan \\
\hline SGK prim teşvikleri tüm iş alanlarını kapsamaktadır. & 2,55 \\
\hline SGK teşvikleri hakkaniyet ölçüsünde verilmektedir. & 2,74 \\
\hline SGK teşvikleri işverenlere yeterince tanıtılmaktadır. & 2,83 \\
\hline $\begin{array}{l}\text { Sosyal Hizmetler Kapsamındakilerin İstihdamına Yönelik Teşvikler uygulaması toplumsal } \\
\text { birlikteliğe katkı sunmaktadır. }\end{array}$ & 3,36 \\
\hline $\begin{array}{l}\text { Uygulanan SGK teşvikleri daha küçük işletmeleri de kapsayacak şekilde küçük oran/tutarlar } \\
\text { biçiminde genişletilmelidir. }\end{array}$ & 4,76 \\
\hline Ortalama & 3,25 \\
\hline
\end{tabular}

SGK prim teşviklerinin genel özelliklerine ilişkin sorulara verilen cevapların ayrıntılı analizi yapıldığında birkaç durumun ön plana çıktığı tespit edilmiştir. Örneğin denetmenlere göre, SGK prim teşviklerinin işverenlere yeterince tanıtılmadığ ş̧eklinde düşüncenin ağır bastığı ifade edilebilir. Bu soruda cevaplayanların sadece yüzde 11,8'inin SGK prim teşviklerinin yeterince tanıtıldığını ifade etmektedir. İlgili soruya katılmayanların oranı \%29,1 olup, kararsızların oranı ise \%59,1 şeklindedir. Bu anlamda SGK prim teşviklerinin yeterince tanıtılması için işyerleri adına prim şartlarını takip etmesi gereken muhasebecilere gerektiğinde eğitim verilmesi, mevzuatı güncel olarak takip etmelerinin sağlanması ve SGK personelinin rehberlik faaliyetlerinin arttırılması ile bu olumsuz algının ortadan kalkabileceği değerlendirilmektedir. Kurum personelinin bu şekilde düşünmesi oldukça dikkat çekici olup, çözümün de yine kurumca karşılanması gerektiği düşünülmektedir.

Diğer ilginç bir sonuç SGK prim teşviklerinin tüm iş alanlarını kapsadığı noktasında denetçilerin olumlu düşünmediği tespitidir. Denetmenlerin yalnızca \%14,5'inin bu olguya katıldıkları tespit edilmiş, kararsız olanların oranı ise $\% 27,3$ şeklinde tespit edilmiştir. Katılmayanların oran $1 \% 56,4$ ve kesinlikle katılmayanların oranı ise $\% 1,8$ olarak belirlenmiştir. Bu soruya katılmama oranı oldukça yüksektir. Uygulanan SGK prim 
teşvikleri alan, bölge ve sektör olarak ayrılmaktadır. İstihdamı arttırmak, kayıt dışı istihdamın önüne geçmek ve gelişmekte olan sektörlerin gelişmesini sağlamak amacıyla teşviklerin uygulama alanının genişletilmesinin gerekli olduğu söylenebilir.

Araştırmanın bu kısmı ile ilgili diğer dikkat çeken bir sonuç ise prim teşviklerinin hakkaniyet ölçüsünde dağıtılmadığına yönelik düşüncedir. Bu konuda denetçiler prim teşviklerinin hakkaniyet ölçüsünde verildiği noktasında tereddüt içerisindedirler. Prim teşviklerinin hakkaniyet ölçüsünde dağıtıldığına inanan denetmenlerin oran $\% 25,4$ (kesinlikle katılanlar \%0,9 ve \%24,5) şeklindedir. Prim teşviklerinin hakkaniyet ölçüsünde verilmediği düşüncesinin fazla olmasının sebebi işveren ve mali müşavirlerin uygulamada prim teşviklerinden faydalanmak adına usulsüz işlemler yapmasından kaynaklanabileceği düşünülmektedir. Birden fazla işyeri olan işverenler teşvik şartlarına uymak adına çalışanlarını fiilen çalışmadıkları diğer işyerlerinden sigortalı olarak göstererek teşvikten yararlanabilmektedir. Denetmenler, bu durumu mevzuata aykırı olmasına karşın, uygulamada karşılaşılan bir durum olarak nitelendirmektedirler.

Tablo 3. İşletmelerin SGK Teşviklerini Alma Çabalarına Yönelik Beklenti Ortalamaları

\begin{tabular}{|l|c|}
\hline İşverenler, SGK teşviklerine hak kazanmak için hukuken doğru olanı yapmaktadırlar. & 3,03 \\
\hline İşverenler SGK teşviklerini almaya yönelik yeterli düzeyde çaba göstermektedirler. & 2,66 \\
\hline $\begin{array}{l}\text { İşverenler, SGK teşviklerine hak kazanmaya yönelik mali kayıtların doğru bilgileri içermesini } \\
\text { önemsemektedirler. }\end{array}$ & 2,69 \\
\hline İşverenler, aldıkları SGK teşviklerinin hangi şartlarda iptal olacağını bilmektedirler. & 3,78 \\
\hline
\end{tabular}

İşletmelerin SGK prim teşviklerinden yararlanma çabalarına yönelik ifadelerin ortalamaları ayrıntılı incelendiğinde ortaya farklı durumların çıktığı tespit edilmiştir. Genel olarak işyerlerinin SGK prim teşviklerini hak etme, almaya çabalama, almak için hukuken doğru olanı yapma ve mali kayıtlarını düzgün bir şekilde tutmayı önemseme noktasında SGK denetmenlerinin büyük bir bölümünün kararsızlık yaşadığ 1 göze çarpmaktadır. Bu noktada işyerlerinin teşviklerden faydalanmak adına usulsüzlüklere başvurabildikleri belirtilmektedir. Örneğin; 2013 yılından beri uygulanan ilave 6 puanlık indirim teşviki, 51 il ile Bozcaada ve Gökçeada ilçelerinde malullük, yaşlılık ve ölüm sigorta primlerinde 5 puanlık prim indirimine ilave olarak, prime esas kazanç alt sınırı üzerinden hesaplanan 6 puanlık indirimden yararlanmaktadırlar. İstanbul ilinde yapılan yerel denetimde fiilen İstanbul'un Kadıköy ilçesinde çalışan bir sigortalının, işverenin 6 puanlık indirim teşvikinden yararlanabileceği 51 ilden birinde olan başka bir işyerinden sigortalı olarak gösterildiği tespit edilmiştir. İşyerine ait yasal defter/belge incelendiğinde kişinin ücret ödemesinin gerçekte fiilen çalışmadığı işyerine ait yasal defterlerde yer aldığı görülmektedir. Bu durumda sigortalının çalışmaları, fiilen çalışmakta olduğu Kadıköy ilçesine ait işyeri dosyasına aktarılarak işverenin usulsüz bir şekilde teşvik unsurlarından yararlanmasının önüne geçilmektedir.

\section{Tablo 4: SGK Prim Teşviklerinin İstihdama Katkı Sağlamasına Yönelik Beklentilerine Yönelik Ortalamalar}

\begin{tabular}{|c|c|}
\hline $\begin{array}{l}\text { İstihdama ilişkin prim teşviklerinden "Genç ve kadın istihdamı (18-29 Yaş Aralığında Olan Erkek ve } \\
18 \text { Yaşından Büyük Kadın)"istihdamı artırma adına olumlu sonuçlar vermektedir. }\end{array}$ & 3,79 \\
\hline $\begin{array}{l}\text { İstihdama ilişkin prim teşviklerinden "Mesleki Belgesi Olan Sigortalı İstihdamı İşveren Hissesi Sigorta } \\
\text { Prim Teşviki” çalışanların eğitim seviyesini artırıcı bir teşviktir. }\end{array}$ & 3,73 \\
\hline $\begin{array}{l}\text { İstihdama ilişkin prim teşviklerinden "Malullük, Yaşlılık ve Ölüm Sigortaları Prim Oranının İşveren } \\
\text { Hissesinden Beş Puan İndirimi” istihdamın artırılmasına olumlu katkı sağlamaktadır. }\end{array}$ & 3,56 \\
\hline $\begin{array}{l}\text { İstihdama ilişkin prim teşviklerinden “Uzun Vadeli Sigorta Kolları Primi İşveren Hissesinin Beş } \\
\text { Puanının Devlet Tarafından Karşılanması” istihdamın artırılmasına olumlu katkı sağlamaktadır. }\end{array}$ & 3,52 \\
\hline $\begin{array}{l}\text { İstihdama ilişkin prim teşviklerinden "Bağımsız Çalışan Sigortalıların Uzun Vadeli Sigorta Kolları } \\
\text { Primlerinin Beş Puanının Devlet Tarafından Karşılanması" istihdamın artırılmasına olumlu katkı } \\
\text { sağlamaktadır. }\end{array}$ & 3,54 \\
\hline $\begin{array}{l}\text { İstihdama ilişkin prim teşviklerinden "Gelişmekte Olan Bölgelerdeki İşverenlerin Çalıştırdıkları } \\
\text { Sigortalılar Adına Ödeyeceği Uzun Vadeli Sigorta Kolları Primi İşveren Hissesi Teşvikine İlaveten } \\
\text { Uygulanan Prim Teşviki” istihdamın artırılmasına olumlu katkı sağlamaktadır. }\end{array}$ & 3,60 \\
\hline
\end{tabular}




\begin{tabular}{|c|c|}
\hline $\begin{array}{l}\text { İstihdama ilişkin prim teşviklerinden "Gelişmekte Olan Bölgelerdeki İşverenlerin Çalıştırdıkları } \\
\text { Sigortalılar Adına Ödeyeceği Uzun Vadeli Sigorta Kolları Primi İşsveren Hissesi Teşvikine İlaveten } \\
\text { Uygulanan Prim Teşviki" sadece gelişmekte olan değil tüm bölgeler için uygulanmalıdır. }\end{array}$ & 4,04 \\
\hline $\begin{array}{l}\text { "İşbaşı Eğitim Programlarını Tamamlayanların İstihdamına Yönelik Teşvikler” yeni istihdam alanları } \\
\text { oluşturmaktadır. }\end{array}$ & 3,57 \\
\hline $\begin{array}{l}\text { "İsssizlik Ödeneği Alanları İşe Alan İşverenlere Yönelik Teşvikler" uygulaması istihdama olumlu } \\
\text { katkı sunmaktadır. }\end{array}$ & 3,48 \\
\hline $\begin{array}{l}\text { “İŞKUR’a Kayıtlı İşsizlerin İşe Alınmasına Yönelik Teşvikler” uygulaması istihdama olumlu katkı } \\
\text { sunmaktadır. }\end{array}$ & 3,55 \\
\hline Ortalama & 3,64 \\
\hline
\end{tabular}

Denetmenlerin SGK prim teşviklerinin istihdama katkısına yönelik görüşlerinin olumluya yakın seyrettiği tespit edilmiştir. Genel olarak bakıldığında denetmenlerin \%81,8'i ilgili görüşe katılmaktadır. Ayrıntılı analiz edildiğinde dikkat çeken konuların şu şekilde olduğu tespit edilmiştir; denetmenlerin SGK prim teşvikleri arasında en çok genç ve kadın istihdamı (18-29 yaş aralığında olan erkek ve 18 yaşından büyük kadın) adına verilen teşviklerin, istihdamı artırması adına kararsız ve olumlu arasında olumluya yakın sonuçlar verdiğini, SGK prim teşvikleri arasında en az oranda "işsizlik ödeneği alanları işe alan işverenlere yönelik teşvikler" uygulamasının istihdamı artırmak adına kararsız ve olumlu arasında olumluya yakın sonuçlar verdiğini düşündüklerini ve işyerlerine verilen teşviklerin daha olumlu sonuçlar vermesi noktasında denetmenlerin "gelişmekte olan bölgelerdeki işverenlerin çalıştırdıkları sigortalılar adına ödeyeceği uzun vadeli sigorta kolları primi işveren hissesi teşvikine ilaveten uygulanan prim teşviki"nin yalnızca gelişmekte olan değil tüm bölgeler için uygulanmasına oldukça yüksek oranda katıldıkları saptanmıştır $(4,04)$.

Uygulanan teşviklerin daha olumlu sonuçlar vermesi adına alan, bölge ve sektör ayrımının ortadan kaldırılması gerekmektedir. Örneğin; gelişmekte olan bölgelerdeki işverenlerin çalıştırdıkları sigortalılar adına ödeyeceği uzun vadeli sigorta kolları primi işveren hissesi teşvikine ilaveten uygulanan prim teşviki yalnızca gelişmekte olan bölgelere uygulanırken, gelişmiş bölgelerde gelişmekte olan sektörler ilgili teşvikten faydalanamamaktadır. Bu durum sektörün gerisinde kalmasına ve kayıt dışı istihdamın artmasına neden olmaktadır. Bu gibi durumların önüne geçmek adına uygulanan teşviklerin tüm bölgelerde uygulanması gerekmektedir.

\section{Tablo 5: SGK Prim Teşviklerinin İşletmelere Mali Destek Sağlamasına Yönelik Beklenti Ortalamaları}

\begin{tabular}{|c|c|}
\hline $\begin{array}{l}\text { SGK prim teşvikleri kapsamındaki vergi matrahı indirimleri işletmelerin kârlılıklarına olumlu etki } \\
\text { etmektedir. }\end{array}$ & 3,85 \\
\hline $\begin{array}{l}\text { "Yurt Dışına Götürülen/Gönderilen Sigortalılar Adına Ödenecek Olan Genel Sağlık Sigortası Primi } \\
\text { İşveren Hissesinin Beş Puanının Devlet Tarafından Karşılanması" işletmelerin personel giderlerinin } \\
\text { azaltılmasına olumlu katkı sağlamaktadır. }\end{array}$ & 3,67 \\
\hline $\begin{array}{l}\text { "Asgari Ücret Desteği” uygulaması işveren ve iş görenlere bütçe katkısı sağlayan bir teşvik } \\
\text { uygulamasıdır. }\end{array}$ & 3,50 \\
\hline Ortalama & 3,67 \\
\hline
\end{tabular}

SGK prim teşviklerinin işletmelere/işverenlere mali destek sağlamasına yönelik denetmen algıları incelendiğinde; denetmenlerin \%70,9'unun teşviklerin mali destek sağladığına katıldıkları, \%25,5'inin kararsız olduğu ve \%3,6'sının teşviklerin mali destek sağladığına katılmadıkları belirlenmiştir. Denetmenlerin büyük bir oranının SGK prim teşvikleri kapsamındaki vergi matrahı indirimlerinin işletmelerin kârlılıklarına olumlu etki ettiğini düşündükleri $(3,85)$ ve "asgari ücret desteği" uygulamasının işveren ve iş görenlere bütçe katkısı sağlayan bir teşvik uygulaması olduğu noktasında ise daha kararsız bir algıya sahip oldukları $(3,50)$ belirlenmiştir. Ayrıca, denetmenlerin "yurt dışına götürülen/gönderilen sigortalılar adına ödenecek olan genel sağllk sigortası primi işveren hissesinin beş puanının devlet tarafindan karşılanması" teşvikinin işletmelerin personel giderlerine olumlu katkı sağlaması noktasında puan ortalamalarının 3,67 ile daha olumlu bir alg1 içerisinde oldukları değerlendirilmektedir.

SGK prim teşvikleri kapsamındaki vergi matrahı indirimleri işletmelerin kârlılıklarına olumlu etki sağlamaktadır. Ancak yapılan destek tüm işverenleri kapsamasına rağmen oranının düşük ve sabit olması sebebiyle büyük işletmelerde oransal olarak daha fazla kârlılık sağlarken, küçük işletmelerde daha az kârlılık sağlamaktadır. Bu nedenle teşvik miktarının artırılması işletmelerin kârlılık oranında daha yüksek paya sahip olmasına katkı sağlayacaktır. 
Tablo 6: SGK Prim Teşviklerinin İşgörenlere Mali Destek Sağlamasına Yönelik Beklenti Ortalamaları

\begin{tabular}{|l|c|}
\hline $\begin{array}{l}\text { “Asgari Ücret Desteği” uygulaması işveren ve işgörenlere bütçe katkısı sağlayan bir teşvik } \\
\text { uygulamasıdır. }\end{array}$ & 3,50 \\
\hline $\begin{array}{l}\text { "Sosyal Yardım Alanların İstihdamına Yönelik Teşvikler” uygulaması işgörenlere mali destek sağlayan } \\
\text { etkili bir uygulamadır. }\end{array}$ & 3,27 \\
\hline $\begin{array}{l}\text { "İş Kazalarının Önlenmesine Yönelik Teşvikler” in çalışanların sağlıklı olarak iş hayatını } \\
\text { sürdürmelerine katkısı bulunmaktadır. }\end{array}$ & 3,43 \\
\hline \begin{tabular}{l} 
Uygulanan SGK teşvikleri işgörenlerin gelirlerinin artmasına pozitif katkı sağlamaktadır. \\
\hline
\end{tabular}$\quad$ Ortalama & 3,90 \\
\hline
\end{tabular}

SGK prim teşviklerinin işgörenlere mali destek sağlamasına yönelik denetmen algıları incelendiğinde; denetmenlerin \%0,9'unun teşviklerin çalışanlara mali destek sağladığına katılmadığını ifade ettiği, \%30,9'unun kararsız olduğu, teşviklerin çalışanlara mali destek sağladığına \%64,5'inin katıldığı ve \%3,6'sının ise kesinlikle katıldığı belirlenmiştir. Buna göre denetmenlerin önemli bir bölümü SGK prim teşviklerinden olan "sosyal yardım alanların istihdamına yönelik teşvikler", "iş kazalarının önlenmesine yönelik teşvikler" ve "asgari ücret desteği" uygulamalarının çalışanlara mali destek sağladığına katılmaktadır. Alt bileşenler açısından düşünüldüğünde denetmenler en az "sosyal yardım alanların istihdamına yönelik teşvikler" uygulamasının işverenlere mali destek sağlayan etkili bir uygulama olduğunu düşünürken $(3,27)$ bunu; "iş kazalarının önlenmesine yönelik teşviklerin çalışanların sağllklı olarak iş hayatını sürdürmelerine katkısının olması" (3,43), "asgari ücret desteği uygulaması işveren ve işgörenlere bütçe katkısı sağlayan bir teşvik uygulaması" olduğu $(3,50)$ takip etmektedir. Uygulanan SGK teşvikleri işgörenlerin gelirlerinin artmasına olumlu katkı sağladığı noktasında ise denetmenlerin puan ortalamasının 3,90 ile en yüksek seviyede olduğu belirlenmiştir.

Sosyal Güvenlik Kurumu tarafından uygulanmış ve uygulanmakta olan prim teşvikleri işverenin maliyeti azaltma yönünde olup, belli şartlara uyulduğunda işverenlere mali destek sağlayan uygulamalardır. $\mathrm{Bu}$ teşvikler sayesinde işverenlerin üzerindeki mali yükün azaltılması hedeflenmektedir. SGK denetmenlerinin görev tanımında yer alan "kayıt dışı istihdamın azaltılması" hususu açısından oldukça verimli bir uygulama olduğu ifade edilebilir.

\section{Tablo 7: SGK Prim Teşviklerinin Muhasebeleştirilmesi ve Kayıt Altına Alınmasına Yönelik Beklenti Ortalamaları}

\begin{tabular}{|l|c|}
\hline $\begin{array}{l}\text { İşverenler, SGK teşviklerine hak kazanmaya yönelik mali kayıtların doğru bilgileri içermesini } \\
\text { önemsemektedirler. }\end{array}$ & 2,69 \\
\hline İşverenler, aldıkları SGK teşviklerinin hangi şartlarda iptal olacağını bilmektedirler. & 3,78 \\
\hline SGK teşvikleri işletmelerin muhasebe kayıtlarında şeffaf ve doğru olarak gösterilmektedir. & 2,44 \\
\hline $\begin{array}{l}\text { Muhasebe meslek mensupları işletmelerin SGK teşviklerine ait mali kayıtları nasıl raporlaştıracaklarını } \\
\text { tam olarak bilmektedirler. }\end{array}$ & 3,19 \\
\hline Uygulanan SGK teşvikleri elektronik uygulamalarla (e-vergi, e-fatura vb.) takip edilebilmektedir. & 3,44 \\
\hline Uygulanan SGK teşvikleri işletmelerin finansal tablolarında kolaylıkla ayırt edilebilmektedir. & 2,78 \\
\hline \multicolumn{1}{|c|}{ Ortalama } & $\mathbf{3 , 0 5}$ \\
\hline
\end{tabular}

SGK denetmenlerinin prim teşviklerinin muhasebeleştirilmesi ve kayıt altına alınmasına ilişkin kararsıza yakın bir bakış açılarının bulunduğu değerlendirilmektedir. SGK prim teşviklerinin muhasebeleştirilmesi ve kayıt altına alınmasına dair ölçeğin ilgili bazı maddeleri tek tek analiz edildiğinde ortaya çıkan denetmen algılarının aşağıdaki gibi olduğu belirlenmiştir;

Denetmenlerin, SGK teşviklerinin işletmelerin muhasebe kayıtlarında şeffaf ve doğru olarak gösterildiği noktasında algı puan ortalamalarının 2,44 ile olumsuza daha yakın seviyede olduğu ve muhasebe meslek mensuplarının işletmelerin SGK teşviklerine ait mali kayıtları nasıl raporlaştıracaklarını tam olarak bildikleri noktasında alg1 puan ortalamalarının 3,19 olduğu ve denetmenlerin bu hususta kararsıza yakın bir alg1 içerisinde olduğu görülmektedir. Örneğin; yapılan yerel denetimde işyerinde fiilen çalışırken görülen sigortalının alınan beyanında, işyerinde sigortasız olarak çalıştırıldığı aylar olduğunu ancak kendisinin tam ve aralıksız olarak 1 yıldır çalıştı̆̆ını beyan etmesi üzerine bu durum işverene sorulmaktadır. İşveren sigortalının doğru beyan vermediğini ifade ederek duruma itiraz eder ise işyerine ait yasal defter ve belgeler incelenmek üzere işverenden talep edilmektedir. Yasal defter/belgeler işveren tarafından ibraz edildiğinde sigortalının resmi olarak işten çıkışının yapıldığı dönemlerde kendisine tazminat ödemesi yapılıp yapılmadığı, istifa 
dilekçesinin olup olmadığı, ücretini elden alıyor ise ücret bordrosu, ücretini bankadan alıyor ise banka kayıtları incelenmektedir. Bunun gibi durumlarda işveren tarafindan sözel baskılara maruz kalınabilmektedir. İşyerlerinde herhangi bir kayıt dışı çalıştırma söz konusu olmadığında yerel denetimler sorunsuz tamamlanmakta iken; kayıt dışı çalıştırmanın söz konusu olduğu yerel denetimlerde çeşitli sorunlarla karşılaşılabilmektedir.

Denetmenlerin, uygulanan SGK teşviklerinin elektronik uygulamalarla (e-vergi, e-fatura vb.) takip edilebildiği noktasında algı puan ortalamalarının 3,44 ile olumluya daha yakın olduğu, uygulanan SGK teşviklerinin işletmelerin finansal tablolarında kolaylıkla ayırt edilebildiği noktasında genel algı ortalamalarının 2,78 ile olumsuza daha yakın olduğu tespit edilmiştir.

Aylık prim ve hizmet belgesi, 5510 sayılı Sosyal Sigortalar ve Genel Sağlık Sigortası Kanununa göre (SSK) kapsamında sigortalı çalıştıran özel nitelikteki işyeri işverenleri/aracı/sigortalıyı geçici olarak devir alanlarca en geç belgenin ilişkin olduğu ayı izleyen ayın 23'ünde, Sosyal Güvenlik Kurumu'na elektronik ortamda verilmesi gereken, çalışan sigortalılara ait hizmet ve prim bilgilerini gösteren, işveren açısından da o ay için ödeyeceği primin tahakkukunu gösteren belgedir (www.mevzuat.gov.tr). Bu belgeyi vermeyi çeşitli sebeplerle unutan işveren Sosyal Güvenlik Kurumu'na ek nitelikli “Aylık Prim ve Hizmet Belgesi” vererek kurum kayıtlarına gerekli düzeltmenin yapılmasını talep etmektedir. Bu durumda işyerine ait tutulması zorunlu yasal defter ve belgeler incelenmek üzere talep edilir ve inceleme sonucuna göre dilekçenin işleme alınıp alınmayacağı değerlendirilir. İncelenen yevmiye kayıtlarında muhasebe meslek mensuplarının karışık tutmuş olduğu ücret kayıtları ayırt etme konusunda zorluklara sebep olabilmektedir. Birden fazla şubeye sahip işyerinin ücret kayıtlarının şube olarak belirtilmeden aynı hesap altında tutulması, muhasebe meslek mensubu açısından da süresinde bildirilmeyen kişinin muhasebe kayıtlarına geçirilmesine sebebiyet verebilmektedir. SGK kayıtları ile uyuşmazlığa neden olduğundan verilen ek nitelikli Aylık Prim ve Hizmet Belgesi'nin kabul edilmemesine neden olabilmektedir. Ücret ödemesi banka kaydı ile kanıtlandığında ise yasa gereği tutulması zorunlu defter ve belgeler geçersiz sayılarak idari para cezası uygulanmaktadır.

Tablo 8: SGK Prim Teşviklerinin Denetimine Yönelik Beklenti Ortalamaları

\begin{tabular}{|l|c|}
\hline $\begin{array}{l}\text { Uygulanan SGK teşviklerinin haksız kazanç temin edilmesi vb. kötü niyetli şekilde kullanımı mümkün } \\
\text { değildir. }\end{array}$ & 1,65 \\
\hline $\begin{array}{l}\text { SGK teşviklerinin usulsüz kullanımının engellenmesine yönelik yasal alt yapı tam olarak oluşturulmuş } \\
\text { durumdadır. }\end{array}$ & 1,87 \\
\hline SGK teşviklerine hak kazanılmasına yönelik denetimler etkili şekilde yapılmaktadır. & 2,79 \\
\hline SGK teşviklerinin amacına uygun alanlarda kullanılmasının denetimi etkili şekilde yapılmaktadır. & 2,51 \\
\hline Ortalama & $\mathbf{2 , 2 1}$ \\
\hline
\end{tabular}

Araştırmaya katılan denetmenlerin SGK Prim teşviklerinin denetimine yönelik algıları incelendiğinde; denetmenlerin çok büyük bir bölümünün $(\% 66,4)$ prim teşviklerinin denetimleri konusunda olumsuz bir alg1 içerisinde olduğu ve \%33,6'sının ise bu konuda kararsılılı yaşadığı tespit edilmiştir. Özellikle denetmenlerin, uygulanan SGK teşviklerinin haksız kazanç temin edilmesi vb. kötü niyetli şekilde kullanımının mümkün olmadığı $(1,65)$ ve SGK teşviklerinin usulsüz kullanımının engellenmesine yönelik yasal alt yapının tam olarak oluşturulmuş olması $(1,87)$ hususlarına büyük oranda katılmadıkları gözlenmektedir.

Teşvik uygulamalarında haksız kazanç ve usulsüzlüklerin önüne geçilmesi amacıyla işverenlere, işyerlerinin kayıtlarını tutan ve işverenlere teşvikler hakkında bilgi veren muhasebe meslek mensuplarına gerekli konularda eğitimler verilerek güncel mevzuatın takibini sağlayabilmeleri sağlanmalıdır. Teşvik unsurlarından faydalanan işyerlerinin denetimi arttırılmalı ve gerek görüldüğünde rehberlik faaliyeti yapılarak usulsüzlük durumlarında karşılaşacakları idari yaptırımlar konusunda bilgilendirilmelidirler. Teşviklerin alan, bölge ve sektör ayrımı kaldırılarak işverenlere maliyet olarak cazip gelen usulsüzlüklerinin önüne geçilmelidir.

Tablo 9: SGK Prim Teşviklerinin Denetimini Yapan Denetçilere Yönelik Beklenti Ortalamaları

\begin{tabular}{|l|c|c|}
\hline $\begin{array}{l}\text { SGK teşviklerinin denetiminde denetim elemanlarından kaynaklanan herhangi bir sorun } \\
\text { bulunmamaktadır. }\end{array}$ & 3,02 \\
\hline $\begin{array}{l}\text { SGK teşviklerinin denetiminde denetçi personelin bilgi seviyesi ve mevzuata hakimiyeti yeterli } \\
\text { düzeydedir. }\end{array}$ & 3,99 \\
\hline SGK teşviklerinin denetiminde denetçi personele işletmelerde gereken kolaylıklar gösterilmektedir. & 2,85 \\
\hline $\begin{array}{l}\text { SGK teşviklerinin denetiminde denetçi personele işletmeler gerekli kayıtları şeffaf olarak } \\
\text { sunmaktadırlar. }\end{array}$ & 2,78 \\
\hline
\end{tabular}




\begin{tabular}{|c|c|}
\hline SGK teşviklerinin denetiminde denetçi personel güven içinde denetim faaliyetini yürütmektedir. & 2,51 \\
\hline SGK teşviklerinin denetiminde denetçiler bağımsız hareket etmektedirler. & 3,16 \\
\hline Ortalama & 3,05 \\
\hline
\end{tabular}

SGK prim teşviklerinin denetimini yapan denetçilere yönelik denetmen algıları incelendiğinde ise; denetmenlerin \%20'sinin prim teşviklerinin denetimini yapan denetçilere yönelik olumlu, \%75,5'inin kararsız ve \% 4,5'inin de olumsuz bir algı içerisinde oldukları belirlenmiştir. Bu maddelere ilişkin algı puanlarının genel ortalamasının ise 3,15 ile kararsıza yakın olduğu saptanmıştır.

Denetmenler tarafından verilen cevaplar ortalamalara göre sıralandığında; puan ortalamasının en az olduğu maddenin, SGK teşviklerinin denetiminde denetçi personel güven içinde denetim faaliyetini yürüttügü $(2,51)$ maddesinin olduğu ve bunu sırasıyla, SGK teşviklerinin denetiminde denetçi personele işletmeler gerekli kayıtları şeffaf olarak sunmakta oldukları $(2,78)$, SGK teşviklerinin denetiminde denetçi personele işletmelerde gereken kolaylıkların gösterildiği $(2,85)$, SGK teşviklerinin denetiminde denetim elemanlarından kaynaklanan herhangi bir sorun olmadığı $(3,02)$ ve SGK teşviklerinin denetiminde denetçilerin bağımsız hareket ettiği $(3,16)$ maddelerinin takip ettiği belirlenmiştir.

Denetmenlerin en yüksek olumlu algısının ise, SGK teşviklerinin denetiminde denetçi personelin bilgi seviyesi ve mevzuata hakimiyetinin yeterli düzeyde olduğu $(3,99)$ şeklindedir.

$\mathrm{Bu}$ kapsamda, denetmenlerin görev alanına giren konularda yapılan denetimlerde işverenler eğer teşvik unsurundan yararlanıyorsa ve işyerinde teşviklerin kesilmesine neden olacak bir usulsüzlük söz konusu ise daha agresif bir tavır sergilemektedirler. Örneğin; işyerinde kayıt dışı bir çalışanın var olması işyerinin yararlanmakta olduğu teşviklerin kesilmesine ve daha önce yararlanmış olduğu teşviklerin ise gecikme faizi ile geri ödenmek zorunda olmasına neden olduğundan yerel denetim esnasında kayıt dışı çalışan kişinin işyeri çalışanı olmadığı iddia edilmesi, denetimin engellenmeye çalışılması, kayıtlar istenildiğinde işyerinde olmadığının ifade edilmesi gibi sorunlarla karşılaşılmaktadır. İşverenler idari para cezası ile karşılaşacaklarının bilincinde olduklarından ya da idari para cezasının denetmen tarafından şahsi bir ceza olduğunu düşünebildikleri için bu gibi yollara başvurabilmektedirler. Bu durum istihdamın kayıt altına alınmasının önünde önemli bir engel teşkil etmektedir.

\section{Tablo 10: SGK Prim Teşviklerinin İşletmelerin Sunduğu Ürünlerdeki Kalite ve Verimliliği Artırmasına İlişkin Bulgular}

\begin{tabular}{|c|c|}
\hline $\begin{array}{l}\text { "Yatırımlara Devlet Yardımları Hakkında Kararlar Gereği Uygulanan Teşvikler” yatırımları artırıcı bir } \\
\text { teşvik uygulamasıdır. }\end{array}$ & 3,62 \\
\hline $\begin{array}{l}\text { "AR-GE Faaliyetlerinin Desteklenmesine Yönelik Teşvikler” tamamıyla AR-GE çalışmalarında } \\
\text { kullanılmaktadır. }\end{array}$ & 2,69 \\
\hline $\begin{array}{l}\text { "Kültür Yatıımları ve Girişimlerine Yönelik Teşvikler" kültürel faaliyetleri destekleyici teşvik } \\
\text { uygulamalarıdır. }\end{array}$ & 3,15 \\
\hline Uygulanan SGK teşvikleri işletmelerin kredibilitesine olumlu katkı sağlamaktadır. & 3,95 \\
\hline $\begin{array}{l}\text { Uygulanan SGK teşvikleri daha küçük işletmeleri de kapsayacak şekilde küçük oran/tutarlar biçiminde } \\
\text { genişletilmelidir. }\end{array}$ & 4,76 \\
\hline Ortalama & 3,63 \\
\hline
\end{tabular}

$\mathrm{Bu}$ maddelere ilişkin denetmenlerin algı puanlarının genel ortalamasının 3,67 olduğu ve bu ortalamanın denetmenlerin algıs1 yönünden olumluya daha yakın olduğu gözlenmektedir. SGK prim teşviklerinin işletmelerin kalite, verimlik ve marka değerini artırmasına yönelik algı faktörünü oluşturan maddeler tek tek incelendiğinde aşağıdaki bulgulara ulaşılmıştır;

"Ar-Ge faaliyetlerinin desteklenmesine yönelik teşvikler"in tamamıla AR-GE çalışmalarında kullanıldığını düşünen denetmenlerin puan ortalamasının 2,69 olduğu ve bu konuda en düşük puan ortalamasına sahip olan maddeyi oluşturduğu tespit edilmiştir. Bunun yanında, "kültür yatırımları ve girişimlerine yönelik teşvikler" kültürel faaliyetleri destekleyici teşvik uygulaması olduğu noktasında oluşan denetmen algilarının puan ortalaması 3,15; "yatırımlara devlet yardımları hakkında kararlar gereği uygulanan teşvikler" in yatırımları artırıcı bir teşvik uygulaması olduğuna yönelik algılarının puan ortalamasının 3,62; uygulanan SGK teşviklerinin "işletmelerin kredibilitesine olumlu katkı sağladiğı” "na yönelik denetmen alg1 ortalamasının ise 3,95 olduğu belirlenmiştir.

$\mathrm{Bu}$ bağlamda, "AR-GE faaliyetlerinin desteklenmesine yönelik teşvikler"in tamamıla AR-GE çalışmalarında kullanılmadığının düşünülmesi, "kültür yatırımları ve girişimlerine yönelik teşvikler"in de kültürel faaliyetleri destekleyici teşvik uygulaması olduğu noktasında oluşan bu algının düşük olmasının 
sebebi; bu alandaki teşviklerin yüksek olması ve maliyetlerini düşürmek isteyen işverenlerin bu teşvikleri usulsüz olarak kullanabileceklerini düşünmelerinden kaynaklandığg değerlendirilmektedir. Denetmenlerin bu konuda olumsuz düşünmelerinin bir diğer nedeni de daha fazla şikayete konu işyerlerinde inceleme yapıyor olmaları ve denetimde karşılaşılan kayıt dışı istihdamın sürekli devam ediyor olmasından kaynaklanabilir. Özellikle sosyo-kültürel etkisi bakımından turizm göz önüne alındığında mevsimlik çalışan kişilerin kayıt dışı çalışmalarının daha fazla olduğu görülmektedir. Bu alanlarda sağlanan teşviklerin işveren maliyetini azalttığı ancak kayıt diş1lı̆̆ın tam olarak önüne geçemediği görülmektedir.

Denetmenlerin en yüksek alg1 puanlarına sahip maddenin Uygulanan SGK teşviklerinin daha küçük işletmeleri de kapsayacak şekilde küçük oran/tutarlar biçiminde genişletilmesinin gerekli olduğunu düşünmeleridir $(4,76)$.

Denetmenlerin uygulanan SGK teşviklerinin daha küçük işletmeleri de kapsayacak şekilde küçük oran/tutarlar biçiminde genişletilmesinin gerekli olduğu konusunda algı düzeyinin yüksek olmasının sebebi; denetimlerde küçük işletmelerde kayıt dışı oranının fazla olması ve denetim esnasında işverenle yapılan görüşmelerde işverenin maliyetlerinin yüksek olması olabilir. Bu nedenle küçük işletmelere uygulanacak teşviklerin bu durumun önüne geçebilecek bir etken olduğu düşünülmektedir.

\subsubsection{SGK Prim Teşviklerine Yönelik SGK Denetmen Algılarındaki Farklılıklarının İncelenmesi}

SGK teşviklerine yönelik denetmen algılarının SGK denetmenlerinin eğitim durumları, kurumdaki unvanları ve mesleki deneyimlerine göre farklılık gösterip göstermediği de incelenmiştir. Bu kapsamda katılımcıların kurumdaki unvanlarına göre farklılık olup olmadığının belirlenmesi amacıyla bağımsız örneklem t testi, katılımcıların eğitim durumu ve mesleki deneyimlerine göre farklılık olup olmadığının belirlenmesi amacıyla da Tek Yönlü Varyans Analizi (One-Way ANOVA) uygulanmıştır.

Yapılan farklılık testlerinde sadece SGK denetmenlerinin SGK prim teşviklerinin işgörenlere mali destek sağlamasına yönelik görüşleri ile mesleki deneyimleri arasında istatistiksel olarak anlamlı bir farklılık olduğu tespit edilmiştir $(\mathrm{p}=0,007 ; \mathrm{p}<0,01) . \mathrm{Bu}$ nedenle farklılık bulunmayan durumların sonuçlarının tablolaştırılmasının anlamsız olduğu düşüncesiyle sadece SGK primlerinin işgörenlere mali destek sağlamasının mesleki deneyim açısından farklılığı sonuçları tabloda yer almaktadır.

\section{Tablo 11: SGK Prim Teşviklerinin İşörenlere Mali Destek Sağlamasına Yönelik SGK Denetmenlerinin Görüşlerinin Mesleki Deneyimlerine Göre Farklılık Sonuçları}

\begin{tabular}{llcccc}
\hline Bağımsız Değişken & & N & $\bar{x}$ & ss & P \\
\hline Mesleki Deneyim & 1 Yildan az & 11 & 4,09 &, 302 & \\
& $1-5$ Yil & 57 & 3,63 &, 587 & $* 0,007$ \\
& $6-10$ Yil $^{1}$ & 25 & 3,76 &, 523 & \\
& $11-15$ Yil & 17 & 3,65 &, 493 & \\
\hline
\end{tabular}

Yapılan post-hoc (LSD) analizi sonucunda ise ortaya çıkan bu farkın 1 yıldan az mesleki deneyimi olan personel lehine olduğu belirlenmiştir. Bu sonuç ise SGK denetmenliği görevine yeni başlayan personelin verilen teşviklerin işgörenlere mali destek sağlamasına yönelik daha olumlu bir yaklaşım sergilediklerini göstermektedir.

SGK denetmenlerinin mesleki deneyimlerinin 1 yıldan az ve 6-10 yıl arasında olduğunda teşviklere daha olumlu baktıkları belirlenmiştir. Mesleki deneyimleri 1 yıldan az olan SGK denetmenleri bu 1 yıllık sürede kendilerine refakat eden alanında uzman kişilerin mesleki tecrübelerinden faydalanmakta ve eğitim sürecinde olduklarından teşvikler konusunda çok fazla bilgi sahibi olmayabilmektedirler. Bu nedenle bu süre içinde olumlu bir algıya sahip oldukları değerlendirilmektedir. Mesleki deneyimleri 11-15 yıl arasında olan SGK denetmenlerinin teşviklere yönelik kararsız algılarının ise, SGK mevzuatının ve teşvik şartlarının sürekli değişmesinin sistemin etkinliğine zarar verdiği şeklindeki algılarından kaynaklandığı söylenebilir. Ancak, SGK denetmenlerinin mesleki deneyimleri ne olursa olsun, tüm gruplarda "kararsız" görüş bildiren katılımcıların ağılıkta olduğunu göstermektedir. Bu durum araştırma yapılan denetmenlerin SGK teşvik sistemine mesafeli yaklaştıkları veya sistemin arzu edilen seviyede etkili olmadığını düşündükleri şeklinde yorumlanabilir. Ayrıca, SGK denetmenlerinin mesleki deneyimleri arttıkça anket sorularına verdikleri cevapların ortalama puanlarının da düştüğü tespit edilmiştir. Bu durum, daha genç personelin SGK teşviklerine daha olumlu algı taşıdığını gösterdiği ifade edilebilir. 


\section{SONUÇ VE ÖNERİLER}

Araştırmanın sonuçlarına göre katılımcıların beklentileri arasında "SGK prim teşviklerinin işletmelere mali destek sağlamasına yönelik beklentilerinin" en yüksek ve "SGK prim teşviklerinin denetimine yönelik beklentilerinin" ise en düşük ortalamaya sahip olduğu belirlenmiştir.

İşyerlerine verilen teşviklerden bazıları belirli sayıda çalışanı bulunan işletmelere verildiğinden teşvikten faydalanma konusunda küçük işletmelerin mağdur olduğu düşüncesiyle denetmenlerin büyük çoğunluğu uygulanan SGK prim teşviklerinin daha küçük işletmeleri de kapsayacak şekilde küçük oran/tutarlar biçiminde genişletilmesinin gerektiğini ifade etmektedirler. Özellikle desteklenmeye ihtiyacı olan küçük ölçekli işletmelerin ve kendi nam ve hesabına çalışan esnafların prim teşviklerinden faydalanması ülke ekonomisi açısından da olumlu yansımalara sebep olacaktır. Ayrıca kayıt dışı istihdamın azaltılmasına ve bu duruma maruz kalan sigortasız işçilerin haklarını elde etmelerine olanak sağlayacaktır.

Denetmenlerin büyük bir bölümü istihdama ilişkin prim teşviklerinden "gelişmekte olan bölgelerdeki işverenlerin çalıştırdıkları sigortalılar adına ödeyeceği uzun vadeli sigorta kolları primi işveren hissesi teşvikine ilaveten uygulanan prim teşvikinin" sadece gelişmekte olan değil tüm bölgeler için uygulanması gerektiğini savunmaktadırlar. Zira "gelişmekte olan bölgelerdeki işverenlerin çalıştırdıkları sigortalılar adına ödeyeceği uzun vadeli sigorta kolları primi işveren hissesi teşvikine ilaveten uygulanan prim teşviki" bu bölgelerde bulunan işyerleri için oldukça büyük avantajlar sağlayan ve işyerlerinin işgücü maliyetlerinin büyük oranda düşmesine neden olan ve bu bölgelerde istihdamın olumlu olarak artmasını sağlayan bir teşvik uygulamasidir.

Denetmenlerin, SGK prim teşviklerinin işverenlere yeterince tanıtıldığı, teşviklerin tüm iş alanlarını kapsadığ1 ve teşviklerin işletmelere hakkaniyet ölçüsünde verildiği noktasında olumsuz düşüncelerinin ve çekincelerinin olduğu belirlenmiştir. Denetmenlerin SGK prim teşviklerinin genel özellikleri konusunda bu tür çekincelerinin bulunması işletmeler ve çalışanlar için olumsuzluk yaratabilecek bir durum olarak düşünülmektedir.

Araştırmanın bir diğer sonucunda denetmenlerin büyük çoğunluğu, uygulanan SGK teşviklerinin haksız kazanç temin edilmesi gibi kötü niyetli şekilde kullanımı ve bu teşviklerin usulsüz kullanımının engellenmesine yönelik yasal alt yapının tam olarak oluşturulması ve işletmelerin teşvikleri muhasebe kayıtlarında şeffaf ve doğru olarak göstermeleri konusunda olumsuz bakış açısına sahip olduğu tespit edilmiştir. Dolayısıyla işverenlere teşvik sisteminin daha iyi anlatılması hususunun, teşviklerde yaşanabilecek haksızlığın önüne geçilmesi, istihdamın gelişmesi ve ülke ekonomisine katkı sağlanması açısından oldukça önemli olduğu değerlendirilmektedir.

Denetmenlerin SGK prim teşviklerinin işletmelere mali destek sağladığı noktasında olumlu bakış açıları bulunmaktadır. Bu bağlamda, uygulanan SGK teşviklerinin "çalışanların gelirlerini artırdığı" ve "işletmelerin kredibilitesine olumlu katkı sağladığı" düşünülmektedir.

SGK denetmenlerinin, işyerlerinde denetim yapan denetçi personelin güven içinde denetim faaliyetini yürüttüğü noktasında tereddütlerinin bulunduğu değerlendirilmektedir. İşletmelerin denetçilere gerekli evrakları hassasiyet ve şeffaflık içinde sundukları yönündeki bakış açıları genellikle olumsuzdur. Ancak, denetmenler denetçi personelin bilgi seviyesi ve mevzuata hakimiyetinin yeterli düzeyde olmasından dolayı görevlerini yaparken bu sorunları aşabildiklerini ve sıkıntıları azaltabildiklerini ifade etmişlerdir.

Araştırmanın ilgili sonuçları doğrultusunda işletmeler için büyük öneme sahip prim teşviklerinin oranlarının artırılması, büyük ölçekli ve belirli iş alanlarında faaliyet gösteren işletmeler için uygulanmakta olan SGK prim teşviklerinin daha küçük ölçekli işyerlerini de kapsayacak şeklide genişletilmesi, işletmelerin SGK prim teşviklerini kötü niyetli kullanımının önüne geçilebilmesi adına denetimlerin değiştirilmesi ve artırılması, SGK prim teşviklerinin tanıtılması ve hakkaniyetle verilmesi konusunda gerekli tedbirlerin alınması, gelişmekte olan bölgelerdeki işverenlerin çalıştırdıkları sigortalılar adına ödeyeceği uzun vadeli sigorta kolları primi işveren hissesi teşvikine ilaveten uygulanan prim teşvikinin tüm bölgelerdeki işletmeler için uygulanması gibi öneriler sunulabilir.

Öte yandan denetmenler özelinde; 10 yılı aşan mesleki deneyime sahip denetmenlerin SGK prim teşviklerine bakış açılarının daha olumsuz olduğu tespit edildiğinden uzun süre denetim görevinde bulunan denetmenlerin motivasyonunu artırıcı faaliyetlerin yapılması ve bu olumsuz havanın ortadan kaldırılması adına daha fazla sayıda genç personelin denetmenlik görevinde bulunmasının sağlanması öneri olarak sunulabilir.

Akademik çalışma bağlamında ise ilgili çalışmanın daha büyük bir örneklemle farklı şehirleri kapsayacak şekilde geniş̧letilmesi ile yapılan araştırmanın sonuçlarının karşılaştırmasının yapılabileceği ve literatüre katkı sağlayacak yeni çalışmaların yapılması önerilebilir. Sadece en güncel teşvikler dikkate alınarak benzer çalışmaların yapılması da önerilebilir. 


\section{KAYNAKÇA}

Bozdemir, Enver, (2018) “AR-GE ve Yenilik Faaliyetlerinde Teşviklerin Muhasebe Standartları Açısından Değerlendirilmesi ve Muhasebeleştirilmesi”, Mali Çözüm Dergisi, Ocak-Şubat, s.13-40.

Esen, Bünyamin, (2018) Türkiye'de İş Sağlığı ve Güvenliği Hizmetlerine Yönelik Teşvik ve Destek Uygulamaları, Uluslararası İş Sağlığı ve Güvenliği Kongresi, Bildiri Tam Metin Kitabı, İstanbul.

http://www.istihdamatesvik.com/tesvikler/yatirimlarda-devlet-yardimlari-hakkinda-kararlar-uyarinca-uygulanan-tesvik/ (erişim tarihi: 02.04.2021).

http://www.sgk.gov.tr/wps/wcm/connect/61cf0852-fe86-4495-ab915bdacec8f74f/sunum_tesvikler_25022021.pdf?MOD=AJPERES (erişim tarihi 01.04.2021).

https://www.mevzuat.gov.tr/MevzuatMetin/1.5.4447-20140910.pdf (erişim tarihi: 11.04.2021).

https://www.verginet.net/dtt/11/Vergi-Sirkuleri-2021-44.aspx (erişim tarihi: 12.04.2021)

Işıklı, İbrahim (2018). Kaza Olmayan İşyerlerine Teşvik Var, https://www.dunya.com/kose-yazisi/kaza-olmayanisyerlerine-tesvik-var/435537 (erişim tarihi:13.04.2021).

İzmirlioğlu, Özlem, (2019) İşverenlere Sağlanan sosyal Sigorta Prim teşviklerinin İstihdama Etkisi ve Uygulamada karşılaşılan Sorunlar: Denizli Örneği. Yayımlanmamış Yüksek Lisans Tezi, Pamukkale Üniversitesi, Sosyal Bilimler Enstitüsü, Denizli.

Kaleli, Ebubekir ve Karaca, Coşkun, (2019) “Türkiye’de Kayıt Dışı İstihdama İlişkin Çözüm Önerileri”, Sosyal Politika Çalışmaları Dergisi, 19, 44, Temmuz - Eylül, s. 769-792.

Koç, Yahya Kemal, (2019) Türkiye'de İstihdamı Arttırmaya Yönelik Devlet Teşvikleri ve İşverene Katkısı. Yayımlanmamış Yüksek Lisans Tezi, Marmara Üniversitesi Sosyal Bilimler Enstitüsü Çalışma Ekonomisi ve Endüstri İlişkileri Anabilim Dalı Çalışma Ekonomisi Bilim Dalı, İstanbul.

Kurt, Resul, (2017) "Sosyal Yardım Alanların İstihdam Teşviki”, https://www.dunya.com/kose-yazisi/sosyal-yardimalanlarin-istihdam-tesviki/369197 (erişim tarihi: 13.04.2021).

Nurdoğan, Ali Kemal, (2019) "Sosyal Sigorta Prim Teşviklerinin Sosyal Güvenlik Kurumu Prim Gelirlerine Etkisi: Ekonometrik Bir Analiz”, Fırat Üniversitesi İİBF Uluslararası İktisadi ve İdari Bilimler Dergisi, Cilt:3,Sayı:2, s.81-106.

Oral, İlhan, (2019), “2018 Yılında Uygulanan Sigorta Prim Teşvikleri Üzerine Düşünceler”, Anadolu Üniversitesi Sosyal Bilimler Dergisi, Cilt/Vol.: 19 - Sayı/No: 4, ss. 221-240.

Özcan, Celal, (2021) “İlave 6 Puanlık Bölgesel Prim Teşviki 2021'de Devam Edecek (mi?)”, https://www.pwc.com.tr/tr/medya/kose-yazilari/celal-ozcan/ilave-6-puanl\%C4\%B1k-bolgesel-prim-tesviki2021de-devam-edecek-mi.html (erişim tarihi: 08.04.2021).

Özdamar, Murat, Sigorta $\quad$ Prim $\quad$ Teşvikleri/ İndirimleri, http://archive.ismmmo.org.tr/docs/SeminerNotlar/05042014/Tesvikler.pdf, (07.05.2020).

Şeker, Sakıp ve Özdemir, Fevzi Serkan, (2010) "Sosyal Güvenlik Priminde Beş Puanlık İndirim Uygulaması ve Muhasebe Kayıtlarında Gösterilmesi”, Muhasebe ve Vergi Uygulamaları Dergisi, 3,s.1-20. 